$\mathrm{DOE} / \mathrm{BC} / 14953-24$

(OSTI ID: 14228)

INCREASED OIL PRODUCTION AND RESERVES FROM IMPROVED COMPLETION TECHNIQUES IN THE BLUEBELL FIELD, UINTA BASIN, UTAH

Quarterly Technical Progress Report April 1, 1998-June 30, 1998

By

Craig D. Morgan

Report Issue Date: June 1998

Performed Under Contract No. DE-FC22-92BC14953

Utah Geological Survey

Salt Lake City, Utah 


\section{DISCLAIMER}

This report was prepared as an account of work sponsored by an agency of the United States Government. Neither the United States Government nor any agency thereof, nor any of their employees, makes any warranty, expressed or implied, or assumes any legal liability or responsibility for the accuracy, completeness, or usefulness of any information, apparatus, product, or process disclosed, or represents that its use would not infringe privately owned rights. Reference herein to any specific commercial product, process, or service by trade name, trademark, manufacturer, or otherwise does not necessarily constitute or imply its endorsement, recommendation, or favoring by the United States Government or any agency thereof. The views and opinions of authors expressed herein do not necessarily state or reflect those of the United States Government.

This report has been reproduced directly from the best available copy. 


\section{DISCLAIMER}

Portions of this document may be illegible in electronic image products. Images are produced from the best available original document. 
$\mathrm{DOE} / \mathrm{BC} / 14953-24$

Distribution Category UC-122

Increased Oil Production and Reserves from Improved Completion Techniques in the Bluebell Field, Uinta Basin, Utah

By

Craig D. Morgan

November 1999

Work Performed Under Contract No. DE-FC22-92BC14953

Prepared for

U.S. Department of Energy

Assistant Secretary for Fossil Energy

Gary Walker, Project Manager

National Petroleum Technology Office

P.O. Box 3628

Tulsa, OK 74101

Prepared by

Utah Geological Survey

1594 West North Temple, Suite 3110

Salt Lake City, UT 84114 
Quarterly Technical Progress Report

$04 / 01 / 98$ - 06/30/98

$19^{\text {th }}$ Quarter of the Project

\title{
Increased Oil Production And Reserves From Improved Completion Techniques In The Bluebell Field, Uinta Basin, Utah
}

Contract DE-FC22-92BC14953 -24

\author{
Gary Walker \\ U.S. Department of Energy \\ National Petroleum Technology Office \\ Contracting Officer's Representative
}

\author{
Craig D. Morgan \\ Program Manager \\ Utah Geological Survey \\ (801) $537-3370$
}

US/DOE Patent Clearance is not required prior to the publication of this document 


\section{OBJECTIVES}

The objective of this project is to increase oil production and reserves in the Uinta Basin by demonstrating improved completion techniques. Low productivity of Uinta Basin wells is caused by gross production intervals of several thousand feet that contain perforated thief zones, water-bearing zones, and unperforated oil-bearing intervals. Geologic and engineering characterization and computer simulation of the Green River and Wasatch Formations in the Bluebell field will determine reservoir heterogeneities related to fractures and depositional trends. This will be followed by drilling and recompletion of several wells to demonstrate improved completion techniques based on the reservoir characterization. Transfer of the project results will be an ongoing component of the project.

\section{SUMMARY OF TECHNICAL PROGRESS}

\section{Drilling and Planned Completion of the John Chasel 3-6A2 Well}

\section{Introduction}

The completion of the John Chasel 3-6A2 well (section 6, T. 1 S., R. 2 W., UBM) is the third step in a three-well demonstration. The first two wells, Michelle Ute 7-1 (sec. 7, T. 1 S., R. 1 E.) and Malnar Pike 17-1 (sec. 17, T. 1 S., R. 1 E.) were discussed in previous reports. The Michelle Ute was planned as a high-diversion, high-pressure, three-stage recompletion. Each stage or interval, was intended to span about 500 vertical $\mathrm{ft}(150 \mathrm{~m})$. Mechanical problems prevented a valid test of this recompletion technique. The Malnar Pike recompletion involved isolation and stimulation of much smaller intervals, testing at the bed scale, or as close to bed scale as was practical. Production results are still erratic but some improvement in the oil production rate was accomplished in the Malnar Pike well.

\section{Drilling and Logging}

Quinex Energy Corporation drilled the John Chasel 3-6A2 well to a total depth (TD) of $15,872 \mathrm{ft}(4837.8 \mathrm{~m})$ in the Flagstaff Member of the Green River Formation. The well appears to have drilled a small overturned repeated section within the Flagstaff (Fig. 1) resulting in a slightly higher than expected structural elevation at the top of the Flagstaff (Fig. 2). The 3-6A2 well is the second deep well in the section, and like most second wells it appears to have been partially depleted. The 3-6A2 well encountered numerous oil and gas shows while drilling in the Green River and Colton Formations but was drilled to TD with a maximum mud weight of $11 \mathrm{lbs} / \mathrm{gal}$. In this part of the Bluebell field the first wells typically required $14 \mathrm{lbs} / \mathrm{gal}$ drilling mud. . Openhole geophysical well logging consisted of dual induction, compensated neutron lithodensity, dipole shear anisotropy, gamma ray, and spontaneous potential. The thermal decay neutron time (TDT) $\log$ was run after the hole was cased.

\section{Evaluation and Planned Completion}

Most wells in the Bluebell field are completed by perforating 40 to 60 or more beds. Perforations are usually selected based on drilling shows with minor reliance on geophysical well 
logs. The objective of completing the $3-6 \mathrm{~A} 2$ well is to use geophysical well logs to select far fewer beds for completion, hopefully reducing completion costs, increasing the production rate, and greatly reducing the volume of water produced. Nineteen beds were selected for perforating, far fewer than in most other wells in the Bluebell field. The TDT log was the primary tool used for selecting perforations, along with consideration given to fracturing identified on the dipole shear log and exceptional drilling shows. The density-neutron porosity log was evaluated but log porosity was not a deciding factor. Table 1 shows the beds selected for perforating and a qualitative analysis of the amount of fracturing and oil saturation based on the shear anistropy and TDT logs, respectively.

The 3-6A2 well will be completed by acidizing the perforations in two separate stages. The first stage will treat beds $1-12$, and the rest will be treated in the second stage. Each stage will contain an isotope tracer. Isotope tracer and production (temperature and spinner) logs will be run to determine how effectively the acid was diverted into each of the beds and which beds are producing hydrocarbons, after the well has been swab tested. The completion of the well should be finished by the end of the next quarter. 


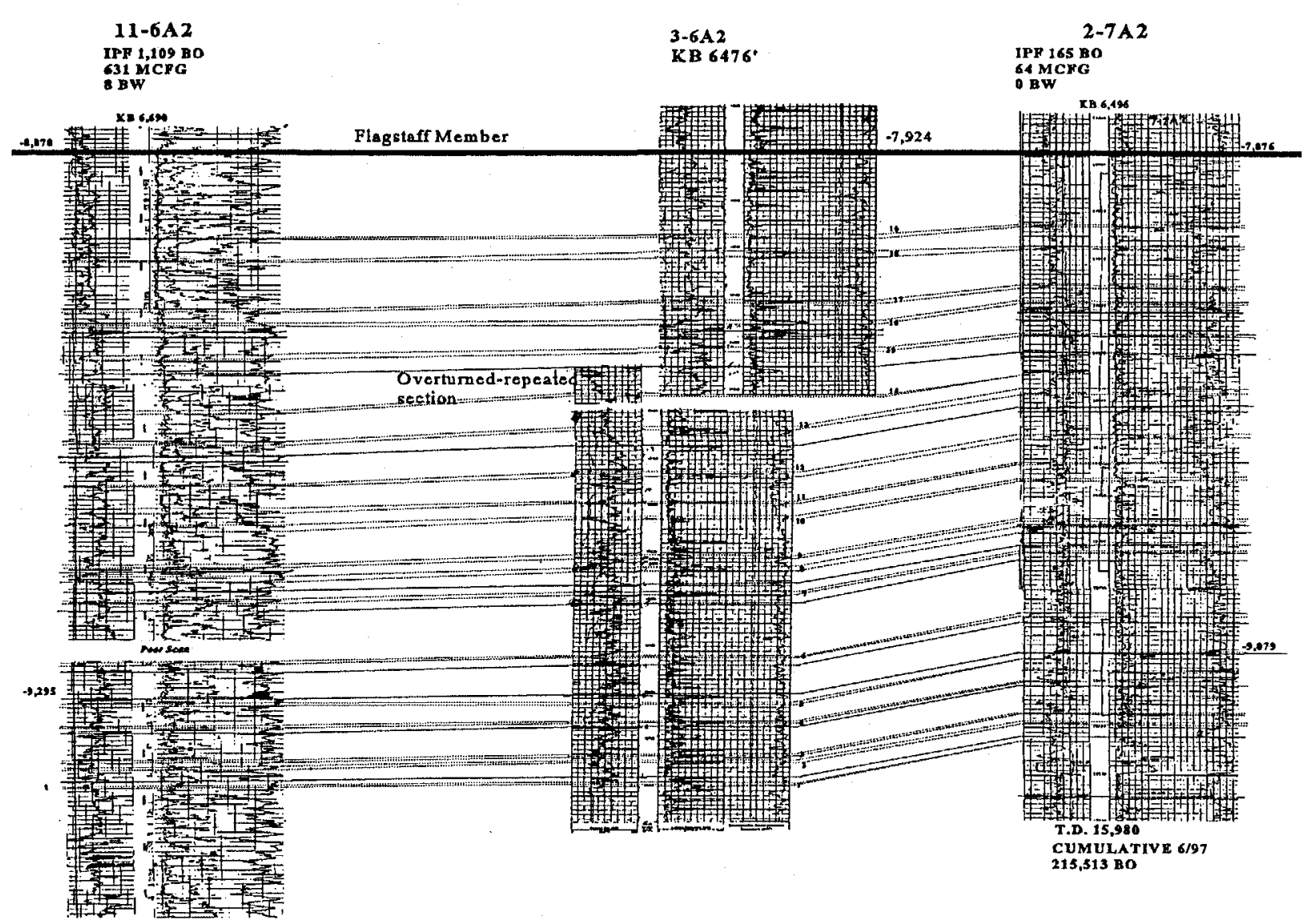

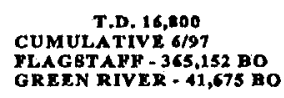

Figure 1. North to south log cross section of the Flagstaff Member of the Green River Formation, location shown on figure 2. The numbers refer to the beds that are scheduled to be perforated in the 3-6A2 well (see table 1). 


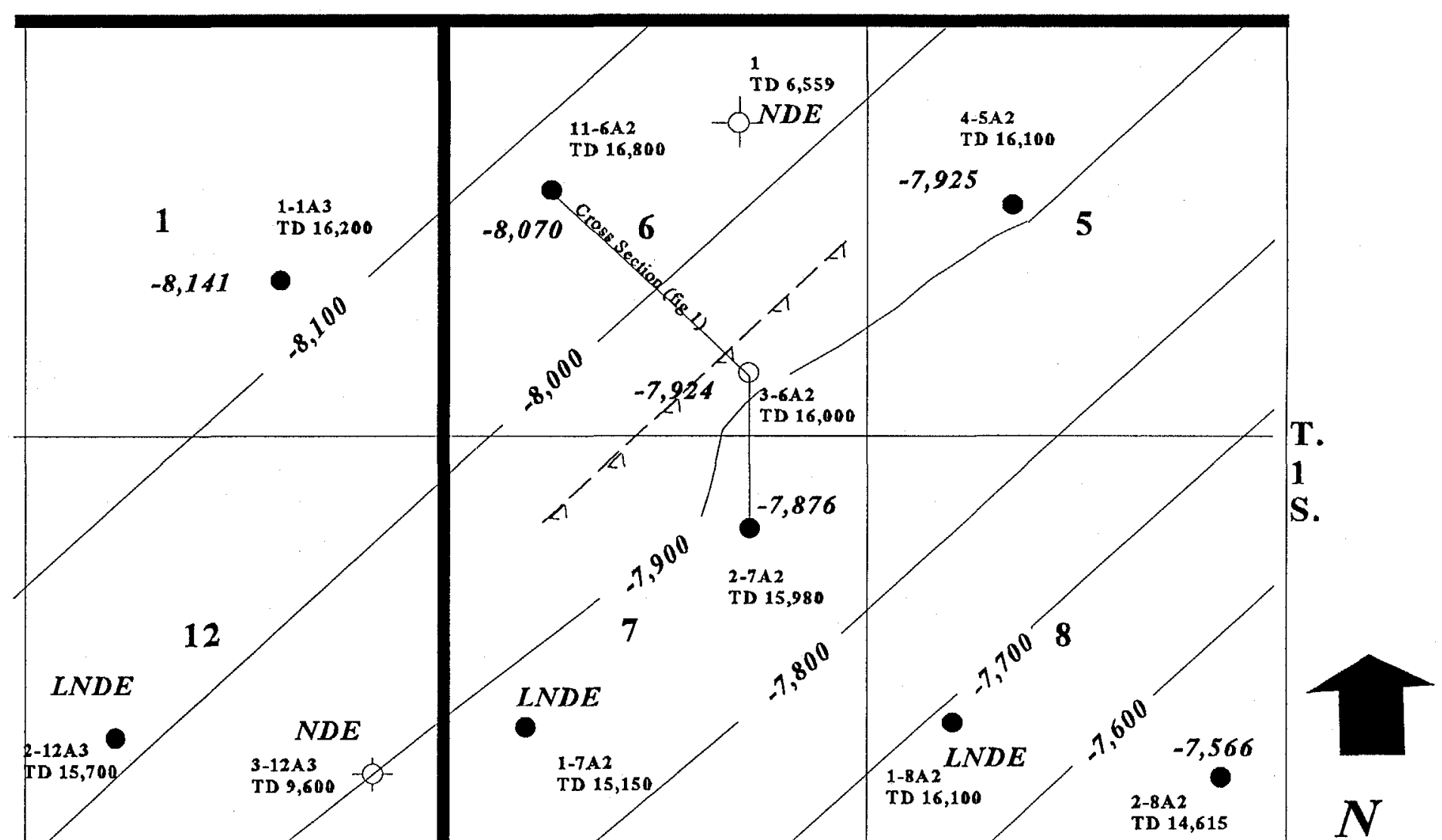

R. $3 \mathrm{~W}$.

oil Well

- Dry Hole

$O$ Location
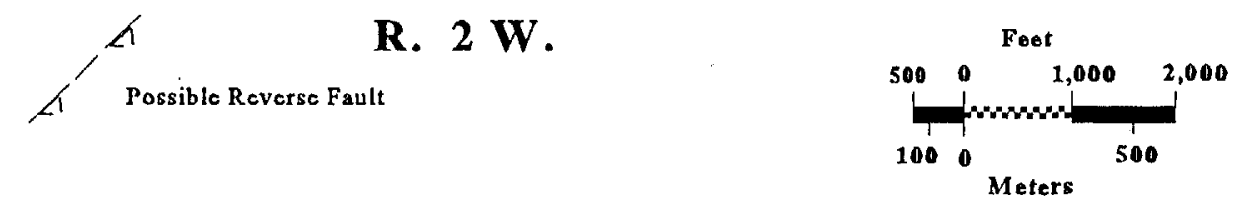

Figure 2. Structure contour map of the top of the Flagstaff Member of the Green River Formation. Sea level datum, contour interval 100 feet. NDE is not deep cnough, LNDE is logs not deep enough. 
Table 1. Preliminary evaluation of proposed perforations for the John Chasel 3-6A2 well. Bed numbers shown on the cross section

\begin{tabular}{|c|c|c|c|c|c|c|c|}
\hline Stage & Bed & $\begin{array}{l}\text { Drill Depth } \\
\quad(f t)\end{array}$ & Drilling Show & $\begin{array}{c}\text { Resistivity } \\
(\text { ohm-m) }\end{array}$ & $\begin{array}{c}\text { Percent Porosity } \\
(D+N / 2)\end{array}$ & $\begin{array}{c}\text { Fractures } \\
\text { (Shear anistropy) }\end{array}$ & $\begin{array}{l}\text { Oil Saturation } \\
\text { (TDT) }\end{array}$ \\
\hline \multirow[t]{12}{*}{ One } & 1 & $15,788-91$ & gas show & 50 & 4 & poor & poor-fair \\
\hline & 2 & $15,746-49$ & oil show & 30 & 5 & poor & poor \\
\hline & 3 & $15,732-34$ & oil show & 50 & 4.5 & poor & fair \\
\hline & 4 & $15,660-62$ & gas show & 25 & 3 & poor & poor \\
\hline & 5 & $15,620-25$ & gas show & 22 & 7.5 & none & wet \\
\hline & 6 & $15,519-21$ & gas show & 17 & 10 & poor & excellent \\
\hline & 7 & $15,384-87$ & none & 28 & 6.5 & base of fracture & good \\
\hline & 8 & $15,334-41$ & gas show & 65 & 7.5 & poor & excellent \\
\hline & 9 & $15,306-14$ & oil show & 28 & 6 & poor & good \\
\hline & 10 & $15,226-30$ & gas show & 15 & 8 & fair & excellent \\
\hline & 11 & $15,191-95$ & oil show & 25 & 10 & fair & poor-fair \\
\hline & 12 & $15,130-36$ & oil show & 25 & 7 & very good & wet-trace of oil \\
\hline \multirow[t]{7}{*}{ Two } & 13 & $15,035-45$ & gas show & 40 & 12 & good & very good \\
\hline & 14 & $14,925-29$ & gas show & 45 & 10.5 & poor & $\begin{array}{l}\text { excellent } \\
\text { (highest oil saturation) }\end{array}$ \\
\hline & 15 & $14,814-16$ & gas show & 20 & 7.5 & good & fair \\
\hline & 16 & $14,752.58$ & gas show & 25 & 5 & poor-fair & poor-fair \\
\hline & 17 & $14,710-14$ & oil show (best show) & 25 & 5 & poor & poor-fair \\
\hline & 18 & $14,608-12$ & gas show & 35 & 8 & good & poor \\
\hline & 19 & $14,574-77$ & oil show (start of strong oil shows) & 20 & 8 & fair-good & excellent \\
\hline
\end{tabular}




\section{Technology Transfer}

A paper entitled Bluebell field, Uinta Basin: Reservoir characterization for improving well completion and oil recovery, by Scott L. Montgomery (AAPG) and Craig D. Morgan (UGS) was published in the American Association of Petroleum Geologists Bulletin, June 1998, v. 82, no. 6, p. 1113-1132.

A poster display entitled Second field demonstration of completion techniques in a (DOE Class I) fluvial-dominated deltaic lacustrine reservoir, Uinta Basin, Utah, by Craig D. Morgan was presented at the American Association of Petroleum Geologists Annual Convention in Salt Lake City, Utah.

Exhibits from the Bluebell project were displayed at the UGS booth at Vernal Petroleum Days in Vernal, Utah, and the AAPG National Convention in Salt Lake City, Utah, during the month of May.

The Utah Geological Survey maintains a Bluebell home page on its web site containing the following information: (1) a description of the project, (2) a list of project participants, (3) each of the Quarterly Technical Progress Reports, (4) a description of planned field demonstration work, (5) portions of the First and Second Annual Technical Reports with information on where to obtain complete reports, (6) a reference list of all publications that are a direct result of the project, (7) an extensive selected reference list for the Uinta Basin and lacustrine deposits worldwide, and (8) daily activity reports of the demonstration wells. The home page address is http://www.ugs.state.ut.us/bluebell.htm 